\title{
History of Protest Literature in India: Trails from the Bhakti Literature
}

\author{
Preeti Oza \\ St. Andrew's College, University of Mumbai, India \\ $<$ Preetioza1@gmail.com>
}

\begin{abstract}
"Better is to live one day virtuous and meditative than to live a hundred years immoral and uncontrolled" (The Buddha)

Bhakti movement in India has been a path-breaking phenomenon that provided a solid shape and an identifiable face to the abstractions with the help of vernacular language. As a religious movement, it emphasized a strong personal and emotional bond between devotees and a personal God. It has come from the Sanskrit word Bhaj- 'to share'. It began as a tradition of devotional songs, hagiographical or philosophical - religious texts which have generated a common ground for people of all the sects in the society to come together. As counterculture, it embraced into its fold all sections of people breaking the barriers of caste, class, community, and gender. It added an inclusive dimension to the hitherto privileged, exclusivist, Upanishadic tradition. It has provided a very critical outlook on contemporary Brahminical orthodoxy and played a crucial role in the emergence of modern poetry in India. This paper elaborates on the positioning of the Bhakti Movement in the context of Protest narratives in India.
\end{abstract}

Keywords- Bhakti literature, protest movements, religion and community

\section{Introduction}

Bhakti Literature as a Protest

Literature:

The term 'Protest' is changing with time and age. The ideas of showing displeasure or oppose any idea are called the protest.

They did express their resentment against unjust economic, social, and religious situations. It may be because there is an inherent tendency in man to protest. The protest of an individual is often reflected as social protest. The protest is the awareness that arises when a man confronts an unjust and inhuman situation and decides to get rid of it by way of raising his voice against it and acting to remove it. 
Bhakti traditions and their literature have had a deep impact on Indian society for centuries. On the one hand, they have served as a language for the expression of existential and social anguish, expressing this often in gendered terms. The injustices of class and caste are a frequent subject of concern. The vernacular poets from different castes, regions, and religions created a bountiful corpus of literature since the eighth century AD in the form of metrical compositions, poems, songs, vachanas, bhajans, keertanas, and padams. A heterogeneous group, they are distinguished by non-sectarian attitude, vernacular idiom, faith in divinity, dismissal of rituals and caste, and affinity with the underprivileged sections.

As Aijaz Ahmed puts it- "“ Bhakti had been associated, on the whole, with enormous democratization of literary language; had pressed the cultural forms of caste hegemony in favor of the artisans and peasants ...was ideologically anti- brahminical; had deeply problematized the gender construction of all dialogic relations."

The Bhakti Movement, though largely associated with medieval India, has roots in the recognizable movement when Alvar saints of the South emerged in the ninth century BCE. It has spread across the subcontinent in different regions and communities and also supported various regional movements. It has also initiated a wave of social, religious and spiritual inquiry. It was more of a spiritual movement than the religious movement. This democratizing movement is characterized by the emergence of many local religious communities and groups revolutionary in nature and spirit. This new spirit was a result of awareness and exposure to a more egalitarian religion- Islam which was introduced by the Mulsim invasion.

\section{Literature Review}

Andrew Schelling, Oxford Anthology of Bhakti Literature. OUP India. 2011 is used to source many authentic English translations of the Bhakti Poetry.M. Rajagopalachary (Editor) and K. Damodar Rao in ' Bhakti Movement and Literature: Reforming a Tradition' provides some of the prominent basics about the nature of Bhakti Poetry and help us to connect it with the idea of protest literature. Ronald Stuart and Mcgregor, in an edited volume on Devotional Literature in South Asia: Current Research, discusses some of the important Bhakti poets and their landmark poems to give a comparative analysis of the study of Bhakti Literature. Jayant Lele in an edited volume Tradition and modernity in Bhakti movements supports the connection between the nature of protest and the regional elements shaping the Bhakti poetry. John Stratton and Hawley, in Songs of the Saints of India, argue on the basic element of Religiosity of Bhakti saints 
and their socio-economic realities in the larger context of contemporary Indian milieu. John Stratton and Howley in Three Bhakti Voices: Mirabai, Surdas, and Kabir in Their Times and Ours provide a very extensive reading of the three important milestones in the Bhakti Literature- Mirabai, Surdas and Kabir. It helps in getting the idea of individualistic treatment to the concept of Bhakti Poetry concerning the Protest literature in their times. Eleanor Zelliot in "Chokhamela: Piety and protest." Bhakti Religion in North India: Community Identity and Political Action discuss a vast panoramic narrative of Chokhamela's Bhakti cult in North India and how it has helped unite the people from different classes and castes. Eleanor Zelliot in "Chokhamela and Eknath: Two" Bhakti" Modes of Legitimacy for Modern Change." Journal of Asian and African Studies compares Chokhamela and Eknath in their respective region and time and the unifying factor of both the poets in the form of Bhakti poetry as the form of revolt and protest. $\mathrm{K}$. Damodar Rao and Madabhushanam in the 'Bhakti Movement and Literature' discusses that as counterculture Bhakti movement embraced into its fold all sections of people breaking the barriers of caste, class, gender, and region. It performed a subversive, reformatory function that changed the dynamics of worship at the religious level and challenged hierarchies at the social level. A heterogeneous group, the bhasha poets are distinguished from non-sectarian attitude, spontaneity and ecstasy, vernacular idiom, and dismissal of rituals. Beena Sengar in 'Historiographic Review of Bhakti Movement In Marathwada' discusses how Bhakti Movement in South Asia and India per se, was a remarkable and distinct kind of socio-religious movement unlike the various socioreligious movements in the history of India. The movement in nature itself questioned the Brahmanism and inherently was instigated by the changed socio-political regime of the early medieval era and its religious idioms. Kumar, Akshaya in "Translating Bhakti: Versions of Kabir in Colonial/ Early Nationalist Period." Indian Literature discusses how Kabir's verses were first translated by the Missionaries in Italian as they were the strong voice of protest against the existing society in Colonial India. Novetzke, Christian Lee in "Bhakti and Its Public." International Journal of Hindu Studies discusses the word 'Bhakti' in two dominant but different modes of describing- Bhakti as a social movement and Bhakti as a personal devotion. He says that all the manifestations of Bhakti are based on performances and for the performances, we need publics for its reception. So basically the term 'bhakti' itself is a word related to people's movement inherently. Satchidanandan, K. in "REFLECTIONS: Kabir Today." Indian 
Literature discusses; Humanness' as a very intense element and powerful element in Kabir's poems. Every line of his verses depicts pain, love, doubt, anger, tenderness, submission, and devotion. Religion for Kabir was a completely inward experience. The impression he has bestowed upon those who followed the externals have lost nothing particularly significant in their daily lives. Majumdar Swapan, in "The Dense Desolate Pathway: Routes of Bhakti in Medieval Indian Literature" discusses that India as a nation lacked political and social unity before the advent of the British. But identitybased on a wide spectrum of religious acculturation was happening silently via bhakti songs and performances. But it is a matter of pity that Bhakti Poetry has hardly been appreciated as a Pan- India phenomenon. or scholars consider Bhakti as a reorientation of Vedic Aryan precepts or historians treats Bhakti as a reaction to the impact of Islam, we cannot but simply feel uneasy about parochial myopia. Das, Sisir Kumar. History of Indian Literature: 1911-1956, struggle for freedom: triumph and tragedy explains the historical development of Protest literature in India during the colonial period. Indian literature as a composite whole is a product of the temper of the time and the infrequent fervor of the protest in the society is well reflected in the contemporary literature. Thapar, Romila. "Dissent and protest in the early Indian tradition." Diogenes discusses the authenticity of the Indian writings and the nature of protest mobilized by these writings. She is arguing the nature of these protests and explains how the protesting witters, for many decades and centuries, are labeled anti-Indian which adds into their woes.

\section{Emergence and Growth}

The emerging Bhakti movement was mainly questioning the religious and orthodox Brahminical interpretation of the Hindu scriptures. It has made the lower caste people and women a part of the new movement. They provided irreligious aspirations, emphasizing devotion and love, not knowledge as a means of salvation. In a newfound burst of confidence, it relocated the bhakti-Marg, Some of the prominent names in the Bhati Movement literature are Ramanuja, Nimbarka, Madhva, Vallabhacharya, Ramananda, Chaitanya, Kabir, Guru Nanak, Dadu Dayal, Mira Bai, Tulsidas, Sur Das, Maluk Das, Sundardas and Narsinh Mehta, Birbhan.

Ramanuja was an Indian theologian, philosopher, and one of the most important exponents of the Sri Vaishnavism tradition within Hinduism. His philosophical foundations for devotionals were influential to the Bhakti movement

Sant Kabir was a 15 th-century Indian mystic poet and saint, whose writings influenced the bhakti 
movement. Kabir's verses are mainly found in Sikhism's scripture Guru Granth Sahib. His most famous writings include his dohas or couplets.

Sant Eknath was a prominent Marathi saint, scholar and religious poet of the Varkari sampradaya. In the development of Marathi literature, Eknath is seen as a bridge between his predecessors-Dnyaneshwar and Namdev-and the later Tukaram and Ramdas.

Guru Nanak was the last to come in the line of the Nirguna Bhakti poets - the "Sants" as they were called popularly He also became the founding saint of another religious tradition, Sikhism.

Mirabai was a mystic poet and one of the central poet-saints of the Bhakti movement, during a difficult period in Indian history filled with religious conflicts.

Sant Narsinh Mehta, also known as Narsi Mehta or Narsi Bhagat, was a 15th-century poet-saint of Gujarat. He is known as a bhakta, an exponent of Vaishnava poetry. He is especially revered in Gujarati literature, where he is acclaimed as its Adi Kavi (Sanskrit for "first among poets")

\section{Importance of Bhakti Literature in the scheme of the world protest literature}

The Bhakti Movement of medieval India embodied a revolt against the inequality inherent in caste as well as against the intellectualism of the traditional paths to salvation (Moksha). Saints and Sufi poets of the medieval period raised their voice against idolatry, the rigors of caste and showed in their writings he futility of such practices. They believed in the love that transcends all. This initial literature echoes the need for social change and freedom from the bondage of caste apartheid. The literary protest is multi-dimensional as it upholds certain values in a specific environment and is concerned with the ironies, contradictions, and paradoxes inherent in the expression of dissent, protest and freeform. A protest writer does not necessarily; seek inspiration from religion, philosophy, or the sociopolitical system.

\section{Bhakti and Social Protest}

The question that lingers here is whether the message of bhakti is a message of social protest. Is the equality it celebrates fundamentally a social reality - and therefore something revolutionary in its Indian context - or is it only spiritual, in which case it can coexist with Brahminical Hinduism even if it does not endorse it?

On the one hand, it seems clear that a poet like Ravidas raises crucial questions about the social order. His perception of Brahmins and others set store by standard Hindu texts and rituals is scarcely complimentary, and he has contempt for all who denigrate people 
belonging to other sectors of society than their own. He insists that

A family that has a true follower of the Lord

Is neither high caste now the low case, lordly or poor.

The number of times he refers to his caste position suggests that he was always mindful of it. On the other hand, he does not propose any religious legislation that would change the current social order. On the contrary, it often seems that he values his lowly position as a vantage point from which the truth about everyone comes more clearly into view. His bhakti vision seems to be not so much that God desires to reform society as that he transcends it utterly, and that in the light of the experience of sharing in God, all social distinctions lose their importance. At the end of the poem most recently quoted, he speaks of how the person of faith may "flower above the world of his birth" as lotuses float upon the water. And he often dwells on the miracle that God has come to him as an implicit sign of how remarkable it is that the holy should touch any human life.

As a result of the Bhakti Movement, the process of building up various regional languages quickened and the foundation was laid for the growth of modern Indian languages. Free from Sanskrit, Pali, Prakrit, and Apabhransha, literature in regional languages entered into a new phase of growth and development.
Consequently, Indian literature and culture broke the shackles of feudalism and seem to have headed towards a more creative, people's culture. Bhakti poetry, liberated from the formalism of ancient poetics, feudalist culture and from the courtly atmosphere, is an expression of people's cultures - their emotions in their languages. Cultural awareness, ideologies, and sensibilities expressed in the Bhakti Movement and its literature are more closely related to culture and society of its times than to ancient traditions of Indian culture and literature. The Bhakti Movement recognizes the absurdities of social systems. It not only portrays the antihuman ideologies of feudalist society in their various aspects and forms but also expresses a feeling of rebellion against them. This spirit of rebellion against feudalism

The most challenging dimension here is that Bhakti literature is experience - based. Here 'experience' takes precedence over 'speculation'. To Dalit writers, history is not illusionary but the firsthand experience. That is why authenticity and liveliness have become hallmarks of Bhakti literature. The similar phenomenon is explored further in the Dalit literature. (Oza, 2018)

Many scholars who have studied the history of Indian culture, literature, and society believe that the process of building up of nationalities started in the 11th and 12th centuries in India. 
The emergence of nationalities meant the beginning of the dissolution of feudalism, the growth of mercantile capitalism and regional languages and literature. Changes in the economic base of society bring about changes in the balance and relationship between various social classes. During the early stages of the formation of nationalism the power of the farmer, craftsman, and the trading class increases. Change in society's economic base and relations of production transform the ideological forms and new possibilities appear for the evolution of art, culture, and literature. The classes which are affected by this new change in economic growth and relations of production play a very important role in literature, art, and culture. There is a very close relationship between the Bhakti Movement and literature on the one hand and the socio-economic changes taking place at the beginning of the 12 th century on the other.

\section{Some of the major aspects of Bhakti Movement as a Protest Literature}

The Bhakti Movement is mainly understood concerning explore voices of discord, rhetoric and cultural contexts in the discourses of Bhakti Movement Literature. It also helps to compare and contrast the artistic maneuvers amongst various Bhakti poets in various areas of protest. It also helps to examine the protest spectrum in the literature of the
Bhakti Movement especially concerning the rise of regional literature and Nationalistic literature. Such discussion will also help to bring in the panoramic understanding of Bhakti Literature in the context of global protest literature and ideologies. It will further help to learn the historical links between forms of protest in different Bhakti Poets in various regions in India and meanings of their individualistic literature

\section{Why the Bhakti Movement is the pioneer of Protest Literature in India}

Bhakti movement literature in general and Bhakti Poetry, in particular, has worked as very significant and noteworthy Protest literature in India and provided a strong base for many other socio-political and religious movements to fight against many social evils. Bhakti movement poetry was more of a spiritual kind than religion. The protest was not the only motto of the Bhakti Poets. The nature and intensity of the protest were the same in the poems of all the poets in the Bhakti movement. Their style, ways of expression, times, regions and religions were different. There is a strong connection between Bhakti Movement literature and literature of Protest in India. The beginnings and growth of the Bhakti Movement and literature have been documented and propagated by several poet-saints across India up to the twentieth century. Rooted in the age and 
the soil their literature is unique in that each of them bears his/her unique stamp of a distinct idiom in their dialogue with God who is like any other human being as He exchanged the roles of a lover, beloved, companion, benefactor, and guide. The main objectives of this study are to include the following areas: To study the Nature of Bhakti Literature with special reference to the element of protest. Such analysis will also help to understand the construction of ideologies of 'Protest Literature' and how they are reflected in Bhakti Literature. To understand the impact and nature of 'Protest' under a wide spectrum of Bhakti literature created in various parts of India. Also to analyze a few poets of Bhakti traditions that are helpful to understand the connection between Protest Literature in India and the emergence of Bhakti literature. To find out grounds on which the people of varying class, castes and creed unite over the Protest element of Bhakti

\section{Literature.}

For who has ever recognized the brilliance of the sun

but by seeing it through eyes gone blind?

The poets we have spoken of so far - Ravidas, Kabir, and Nanak belong to a single branch of the family tree of medieval Indian devotional saints: the nirguna branch. They insist that God, more than any other reality, exceeds the shapes using which human senses interpret the world, and hold therefore that to move in the direction of truth is to leave those senses behind, particularly those that are most successful in convincing us that the world is solid, definite, and real. Among such senses are taste and touch, but the standard-bearer is sight. In the realm of faith, as in ordinary perception, seeing is an enormous part of believing - particularly in Hinduism, with its powerful iconic thrust - and it was just this illusion that the nirguna poets tried to combat. For if one trusted God to the senses, especially to sight, one objectified him, one saw him "out there" rather than grasping the truth that the only real access is from the inside, through one's heart and soul. So interior is Nanak's conception of faith, indeed, that the very word God- or rather Ram, its closest equivalent in medieval north India - rarely occurs in what he says. In poem after poem, he tries to guide us toward recognizing the deepest truth by encouraging us to put aside the eyes with which we are accustomed to seeing.

\section{The Saguna Saints}

The other side of the bhakti family tree features saints of a markedly different persuasion. They are the saguna group, who affirm that what makes for illusion in this world has less to do with our senses as such than with the uses to which we put them: we construct our fantasies and delusion from the inside out, driven by appetite and desire. Given this 
derangement of the inner person, one of how God acts to restore proportion and direction is to assume a sensory manifestation, particularly one that can be seen and visualized. It is a miracle of the religious life, saguna poets and theologians say, that what people see can have a permanently steadying effect on them, as corresponding images are formed within. The Hindu temple, with its array of icons, encourages this miracle to happen as worshipers come to have "sight" (darsan) of the divinities housed there. The saguna perspective maintains that a central feature of divine grace is God's consent to become available to human perception "with attributes" in this way, not just in temple images but in full self-manifestations that have rescued and inspired history from age to age. No one denies that God exceeds what humans can imagine, but insofar as the remedying of our error and misery is concerned, saguna thinkers find it more important and more remarkable that God meets us in the world we inhabit, stretching our sense of what is possible.

The three singer-saints mentioned earlier - Surdas, Mirabai, and Tulsidas (or Sur, Mira, and Tulsi for short) - are saguna poets, devotees identified with one of the personal forms of god. For Sur and Mira this is Krishna, the god whose playful childhood is proverbial in India and whose amorous youth and maturity exert a sweet fascination. Krishna has a heroic side too: as an infant he was capable of miraculous feats against threatening demons; as a young man he defeated the evil king who had usurped the throne of Mathura, the city at the heart of Braj, not far south of Delhi; and as a mature figure, he played a critical advisor role in the world-scale battle that is the subject of India's great epic, the Mahabharata. But Krishna's heroic aspect, though historically the more venerable portion of his mythology, serves only as a background for the major concerns of Sur and Mira. It is Krishna's playful, amorous side that draws them.

Some examples:

A family that has a true follower of the Lord

Is neither high caste now low case, lordly or poor. (Ravidas)

Brother, if holding back your seed Earned you a place in paradise, eunuchs would be the first to arrive (Kabir)

Vedas, Puranas - why read them?

It's like loading an ass with sandalwood!

As for Muslim priorities, such as the necessity of circumcision:

If God had wanted to make me a Muslim, why didn't he make the incision?

Or the practices of naked mendicants:

If the union yogis seek

Came from roaming around in the buff, every deer in the forest would be saved.

Then there are his numerous reflections on life:

Your chance of human birth Doesn't come time and again Once the ripe fruit falls You can't stick it back on the branch. (Kabir) 


\section{Conclusion}

All the poets we have just mentioned were woven together in a single fabric of shared identity before God that extends throughout India's long medieval period (ca. 500-1700 C.C) - this although their regional languages might initially have seemed to separate them. Singers travel, they go on tour, and then as now people living in India could speak more than a single language, so it was no mystery that these Bhakti poet-singers and others who sang their songs after them could be understood as they moved around. It says that all the poets we have just mentioned were woven together in a single fabric of shared identity before God that extends throughout India's long medieval period (ca. 500-1700 C.C) - this even though their regional languages might initially have seemed to separate them. Singers travel, they go on tour, and then as now people living in India could speak more than a single language, so it was no mystery that these Bhakti poet-singers and others who sang their songs after them could be understood as they moved around. As they traveled, we are told, they shaped a history that made India's many regions connect at a grass-roots level. For many who have told the story of the Bhakti movement, Bhakti appears as an independent, living being, something that rides above distinctions of power and status with an agency all its own - a persuasive, at times overwhelming presence that cam moves through history and shape it to its ends. To see things this is to challenge a major way in which Hindus have conceptualized the religious heritage that makes them who they are: sanātana dharma, the idea that Hinduism, often interpreted not as a doctrinal system but as a way of life, is uniquely stable, Hindus like something that characteristically moves, travels and develops. In the image of the Bhakti movement, we meet a Bhakti that is organic and has a life of its own. It is capable of change and development; indeed, it has moved history.[]

\section{Bibliography}

Ahmad, Aijaz.2000. 'The Communist Manifesto and 'World Literature'." Social Scientist (2000): 3-30.

Afrocentric Visions: Studies in Culture and Communication, 1999, Sage Publications. The USA.

Ambedkar B. R., Dr. 1978, Babasaheb Ambedkar's Writings and Speeches, vol 1, Education Department, Government of Maharashtra, Bombay.

Andrew Schelling, 2011, Oxford Anthology of Bhakti Literature. OUP India.

Behl, Aditya. 2007 "Presence and Absence in Bhakti: An Afterword.” International Journal of Hindu Studies, vol. 11, no. 3, 
Bheemaiah, J, 2011, “Theorizing Dalit Metaphor: The Impact of Contemporary Social Protest Movements in India.” International Journal of English: Literature, Language \& Skills.

Bhowmik, Davinder \& Steve Rabson. 2016, Islands of Protest: Japanese Literature from Okinawa University of Hawai Press.

Burchett, Patton. 2009, "Bhakti Rhetoric in the Hagiography of 'Untouchable' Saints: Discerning Bhakti's Ambivalence on Caste and Brahminhood." International Journal of Hindu Studies 13.2

Callewaert, Winand M., 1980. ed. Early Hindi Devotional Literature in Current Research: Proceedings of the International Middle Hindi Bhakti Conference (April 1979) Organized by the Katholieke Universiteit Leuven. Vol. 8. Department Orientalistiek.

Dangle, Arjun. 1992. Poisoned Bread: Translations from Modern Marathi Dalit Literature. Orient Longman.

Das, Sisir Kumar. 2005. History of Indian Literature: 1911-1956, struggle for freedom: triumph and tragedy. Vol. 1. Sahitya Akademi.

Drake, Kimberly. 2013. The literature of Protest. Salem Press.

Faye, Harrison.2008. Outsider Within: Reworking Anthropology in the Global Age. Urbana: University of Illinois Press.

Faye, Harrison. 1995. The Persistent Power of "Race" in the Cultural and Political Economy of Racism. Annual Review of Anthropology 24:47-74.

Guru, Gopal, 2008. Humiliation: Claims and Context. Oxford University Press Delhi.

Hawley, J.S., 2005. Three Bhakti Voices: Mirabai, Surdas, and Kabir in Their Times and Ours. Oxford Univ. Press.

Hilliard, Nunn, 1998. Representing African Women in Movies in J. D. Hamlet (Ed.),

Kumar, Akshaya. 2006. "Translating Bhakti: Versions of Kabir in Colonial/Early Nationalist Period." Indian Literature, vol. 50, no. 1.

Larson, Gerald James, 2007. "Scholarship on Religion and Communities of Faith," Journal of Hindu-Christian Studies: Vol. 20.

Lele, Jayant, 1981. ed. Tradition and modernity in Bhakti movements. Vol. 31. Brill Archive.

Lohia, Rammanohar, 1964. The Caste System, Rammanohar Lohia Samta Vidyalaya Nyas, Hyderabad

M. Rajagopalachary (Editor), K. Damodar Rao, 2016. Bhakti Movement, and Literature: Reforming a Tradition, Rawat Publications.

MAJUMDAR, SWAPAN. 1992. "The Dense Desolate Pathway : Routes of Bhakti in Medieval Indian Literature.” Indian Literature, vol. 35, no. 3.

McGregor, Ronald Stuart, 1992. ed. Devotional Literature in South Asia: Current Research, 1985-1988. Vol. 46. Cambridge University Press.

Nath, J.P.,2002. Socialist Leadership in India, Kanishka Publishers, New Delhi.

Novetzke, Christian Lee.2007. “Bhakti and It's Public.” International Journal of Hindu Studies, vol. 11 , no. 3 .

OZA, D.P., 2018. Aesthetics of Sublime V/S Subliminal: Comparison and Contrast in Dalit Writings. Dr. Vivekanand Jha, 3(1), p.132.

Pandey Sangram lal, 1965. 'Existence, Devotion and Freedom'Allahabad, Darshan Peeth .

Patricia D. Netzley, 1999. Social Protest Literature: An Encyclopedia of Works, Characters, Authors, and Themes. ABC-CLIO Literary Companion. 
Ramanujan, Attipat Krishnaswami. 2004. The collected essays of AK Ramanujan. OUP India.

Rao, K Damodar, and Madabhushanam Rajagopalacharya. 2017. "Bhakti Movement and Literature." Rawat Publications, Jaipur .

Reed, T.V. 2005. "Introduction" and "Reflections on the Cultural Study of Social Movements." in the Art of Protest: Culture and Activism from the Civil Rights Movement to the Streets of Seattle. Minneapolis: University of Minnesota Press.

Satchidanandan, K.1999. "REFLECTIONS: Kabir Today.” Indian Literature, vol. 43, no. 6 (194).

Satyanarayana, Adapa.1995."Dalit protest literature in Telugu: A historical perspective." Economic and Political Weekly.

Sharan Kumar Limbale and Jaydeep Sarangi.2018. Dalit Voice: Literature and Revolt. Authors Press, New Delhi.

Singh, Bhai Jodh. 2000. "Bhagat Ravidas: Jiwan Te Rachna (Bhagat Ravidass: Life and Works)." Patiala: Punjabi University

Thapar, R. 1981. Dissent and Protest in the Early Indian Tradition. Diogenes, 29(113-114), 31-54. https://doi.org/10.1177/039219218102911302

Zelliot, Eleanor. 1980. "Chokhamela and Eknath: Two" Bhakti" Modes of Legitimacy for Modern Change." Journal of Asian and African Studies.

Zelliot, Eleanor. 1995. "Chokhamela: Piety and protest." Bhakti Religion in North India: Community Identity and Political Action.

Zelliot, Eleanor.1982. "The Medieval Bhakti Movement in History: An Essay on Literature in English.” Hinduism. BRILL.

Zoe, Trodd.2008. American Protest Literature, Belknap Press of Harvard University Press. 